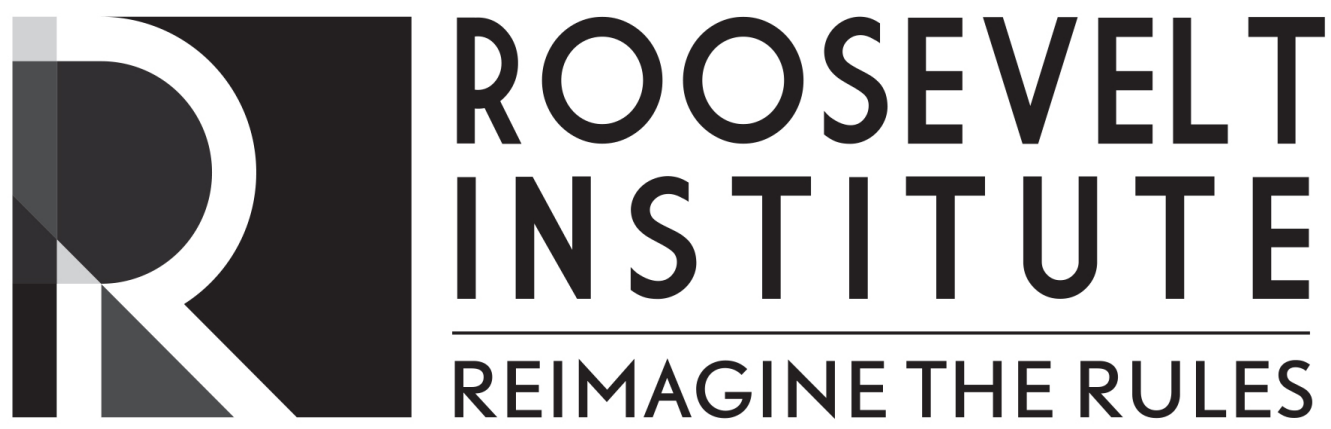

\title{
TOWARDS A BROADER VIEW OF COMPETITION POLICY
}

Roosevelt Institute Working Paper

\author{
Joseph E. Stiglitz ${ }^{1}$ \\ University Professor, Columbia University, Chief Economist at the \\ Roosevelt Institute
}

June 2017

\footnotetext{
${ }^{1}$ University Professor, Columbia University. This a revised draft of a lecture originally presented to the 4th BRICS International Competition Conference in Durban, November 2015. I am indebted to Laurence WilseSamson for helpful comments on an earlier draft, to Steven Salop and Michael Cragg for discussions over the years on the broader issues of antitrust, and to Eleanor Fox for extremely helpful comments on an earlier version. I am also thankful for research and editorial assistance from Matthieu Teachout and Debarati Ghosh. Financial support to the Ford Foundation Inequality Project at Roosevelt Institute and Columbia University is gratefully acknowledged.
} 


\begin{abstract}
For over a hundred years, competition policy has been a central part of a market economy's legal framework. Over the past third of a century, however, the scope and effectiveness of competition policy has been narrowed under the influence of certain ideas about the functioning of the market economy, sometimes referred to as the Chicago School of Law and Economics-ideas which have subsequently been widely discredited within the economics profession, but whose influence within antitrust law remains significant. This paper argues that, to the contrary, changes in our economy and our understandings of the interplay between economics and politics necessitates a broader reach for competition policy even than envisaged by the original advocates of antitrust law. This takes on particular significance with recent reports, such of that of the Council of Economic Advisers of President Obama, highlighting the increase in market power across many important sectors of the US economy and persistent higher rates of return to capital than seem consistent with competition. These monopoly rents may, in turn, play an important role in the country's growing inequality.
\end{abstract}


For over a hundred years, competition policy has been a central part of a market economy's legal framework. Over the past third of a century, however, the scope and effectiveness of competition policy has been narrowed, under the influence of certain ideas about the functioning of the market economy-ideas which have subsequently been widely discredited within the economics profession, but whose influence within antitrust law remains significant. This paper argues that, to the contrary, changes in our economy and our understandings of the interplay between economics and politics necessitates a broader reach for competition policy than envisaged by the original advocates of antitrust law, and that this is especially so in developing countries and emerging markets.

\section{BRIEF HISTORY OF COMPETITION POLICY (ANTITRUST)}

Competition policy (antitrust) began in the United States as a political agenda, to limit the market and political power of trusts (monopolies and oligopolies). Of course, long before that, economists had recognized that competition was necessary if the market economy was to achieve efficient outcomes ${ }^{2}$, and that firms on their own strive to limit competition. As Adam Smith put it,

"People of the same trade seldom meet together, even for merriment and diversion, but the conversation ends in a conspiracy against the public, or in some contrivance to raise prices."

- Adam Smith, The Wealth of Nations

Market power has, of course, distributive effects as well. The monopolist's monopoly rents come at the expense of consumers: as monopolies raise their prices, their profits increase while the well-being of consumers and workers decrease. An increase in market power is associated with an increase in inequality.

This is even more the case for monopsony power, that is, when a firm has market power over its "suppliers." This is especially so when a firm has market power in a labor market, e.g. in a company town. It is costly for workers to move, and thus a monopsonist can lower wages significantly below the competitive level without losing all, or even a significant fraction, of his workers.

\footnotetext{
${ }^{2}$ Though it was not until the 1950's, with the work of Arrow and Debreu, that the efficiency of competitive markets was established (Arrow and Debreu (1954)). An essential assumption was that every firm and household was a price taker, i.e. was so small that nothing that it did could affect market prices. In the real world, there are few instances in which this is true. Agriculture is one-but then there is massive government intervention, because markets on their own lead to high volatility in prices and farmers typically couldn't manage the risks well on their own, and the economy, on its own, didn't develop the institutions and markets to help individuals do so. And even in agriculture, there is heavy concentration in marketing. Some sectors are characterized by monopolistic competition-many firms, but still, each faces a downward sloping demand curve (Chamberlin, 1933; Dixit and Stiglitz, 1977; Stiglitz, 1987). Antitrust typically has not taken an active role in such sectors.
} 
Workers sometimes try to band together, to provide some balance of power. Historically, employers have often countered through physical violence. When that is frowned upon, they turn to political action-to try to ban unions (as a "conspiracy in restraint of trade").

Adam Smith talked about these efforts of workers for collective action, the attempt by employers to suppress such efforts, and how appropriate government regulation of the market-as we would put it today, writing the right rules of the game in the right way (see Stiglitz et al., 2015)-can improve matters:

"Masters are always and everywhere in a sort of tacit, but constant and uniform, combination, not to raise the wages of labour above their actual rate.... Masters, too, sometimes enter into particular combinations to sink the wages of labour even below this rate. These are always conducted with the utmost silence and secrecy." (Smith 1776, Chapter 8.)

When workers combine, "the masters ... never cease to call aloud for the assistance of the civil magistrate, and the rigorous execution of those laws which have been enacted with so much severity against the combination of servants, labourers, and journeymen.” (Smith 1776, Chapter 8.)

"When the regulation, therefore, is in support of the workman, it is always just and equitable; but it is sometimes otherwise when in favour of the masters." (Smith 1776, Chapter 10, emphasis mine.)

Thus, from the earliest days of capitalism, there has been a political battle over the rules of the game-with employers seeking to make it more difficult for workers to engage in collective bargaining/unionization, but with firms resisting efforts to restrain themselves and their anticompetitive behavior.

All of this makes it clear that politics and economics cannot be separated. The early "trustbusters" were concerned about the agglomeration of economic power; but they were also concerned about the associated agglomeration of political power. An agglomeration of economic power almost inevitably results in an agglomeration of political power-which can and typically does reinforce the agglomeration of economic power.

\section{The Chicago School}

In the United States (and elsewhere) courts have been captured by a particular view of the economy, sometimes referred to as the Chicago school (named after the University of Chicago, where many of its prominent members taught), which holds that markets are naturally competitive. In this view, there was in fact relatively little need for government to intervene to ensure competition. The consequences of the Chicago school were broader: competition policy shifted to a narrow economic focus, away from the broader societal consequences of concentrations of power. And within economics, doctrines that markets 
were naturally competitive and efficient meant a strong presumption that any observed behavior, as strange as it might seem, was really efficiency enhancing and supportive of competition. The attractiveness of this shift from the perspective of the judiciary was perhaps understandable: they were given a well-defined question to examine. Was there evidence, in a particular market, of market power? Was there evidence that firms were acting in an anticompetitive way, unfairly using their market power?

Over time, as the influence of the Chicago school grew, so did the presumption that markets were competitive. Even when there was some evidence that there were actions which were anticompetitive, courts looked for offsetting efficiency-enhancing benefits. ${ }^{3}$ While in the US, there was a "rule of reason" in balancing the efficiency and anticompetitive effects, there increasingly developed a presumption that firms' actions are efficiency-enhancing. Similarly, in assessing whether a firm was engaged in predatory behavior, there developed a presumption that it was not: after all, firms were rational, entry barriers were low, and so even if a firm were successful in driving out competitors, there would be new entrants. Thus, no rational firm would engage in selling below costs to drive out others; ergo, predation didn't exist. Courts held this view, even when there was overwhelming evidence that firms were engaged in loss-making activities in order to establish a more dominant position in the future. ${ }^{4}$

There was also the presumption that distribution does not matter, reflected in the use of a total welfare standard, where adverse impacts on consumers could be set against positive benefits to the corporate sector. ${ }^{5}$ Such a perspective is particularly perverse both from an economic and moral point of view in South Africa and other emerging markets. Equally importantly, these perspectives are also increasingly out of sync with developments in modern economics.

\section{Developments in modern economics}

Modern economic theory (including advances associated with information asymmetries and game theory) has rejected all of the central tenets of Chicago School. In particular:

(a) Even competitive markets are not, in general, efficient. As Greenwald and Stiglitz (1986) explain, Adam Smith's invisible hand is invisible because it is not there. This

\footnotetext{
${ }^{3}$ The competition framework of different countries has evolved differently. Not surprisingly, the Chicago school had less influence in many countries, such as South Africa and EU, than it did in the US. Eleanor Fox notes that: The European Union competition law, for example, rejects the Chicago school free market assumptions and privileges openness of markets and access to them by firms without power. See Fox 2014, 2008.

${ }^{4}$ Notice that even if firms did so irrationally, with the costs of predation exceeding the benefits, there can be significant anticompetitive effects, e.g. in discouraging entry.

5 As Eleanor Fox has pointed out, "the US mantra IS that distribution does not matter, but perhaps surprisingly US uses a consumer welfare standard and does not consider it distributive. The animus is against distribution to small business.”
} 
is true whenever there are imperfections of information and risk markets, or endogenous knowledge (innovation) - that is, always.

(b) Markets are not, in general, competitive: Even small deviations from perfect competition and perfect information matter (Diamond 1971; Rothschild and Stiglitz 1976; Stiglitz 1987). Recent advances have shown that there exists a wide range of mechanisms by which market power is acquired, maintained, and enhanced.

(c) Inequality matters. Recent studies (OECD 2014; Ostry, Berg, and Tsangirides, 2014; Stiglitz, 2012) have shown that distribution does matter for economic performance. Moreover, the Second Welfare Theorem (suggesting that issues of efficiency and distribution can be separated, so that economics should only focus on efficiency) does not in general hold (see, e.g. Stiglitz, 2002). In addition, there is increasing evidence that significant parts of inequality are a result of market power (e.g. Furman and Orzsag, 2015).

The fact that there are so many instances of anticompetitive behavior means that the key issue now is selectivity, identifying the most important abuses to prosecute.

\section{NEW PRESUMPTIONS}

The most important implication of this new view is that it changes presumptions. Under the old presumptions, those challenging a seemingly anticompetitive practice had a heavy burden to show that it could not be or was not likely to be or might not be in reality efficiency-enhancing, in which case intervening in the natural workings of the market would lead to a decrease in welfare. Under the new view, there is a much stronger presumption that firms are engaged in some form of exploitive activity-trying to garner for themselves profits at the expense of rivals or consumers.

More successful firms then may not be those who are more able to produce products that consumers love and to do so at lower costs; but rather firms that are better able to create and exploit market power, including taking advantage of consumers. In this view, for instance, Microsoft ${ }^{6}$ may have been so successful only to a limited extent because of its technological innovations; more important were its business innovations, which created new barriers to entry and allowed it to entrench its power and fend off emerging competition that threatened its monopoly. ${ }^{7}$ Akerlof and Shiller (2015) describe the success of firms based on "phishing for phools," and elsewhere (Stiglitz 2010), I have described how globalization opened up a global market place of fools that American financial firms could exploit. This kind of "competition" can be even more distorting than monopoly, because of the efforts/practices aimed at increasing market

\footnotetext{
${ }^{6}$ Remarkably, the court alleging that Microsoft used leverage in OS to get dominance in an applications market, browsers, failed. In the interest of full disclosure, I served as an expert witness against Microsoft in anti-trust actions undertaken in the U.S., Europe, Korea, and Canada.

${ }^{7}$ See below for a brief description of some of these business practices.
} 
power, with consequences that go well beyond simply raising prices. ${ }^{8}$ The intent of these practices is to create entry barriers and to foreclose and reduce competition; the effect is often to stifle innovation and to enhance the ability of the monopolist to exploit its customers and suppliers. ${ }^{9}$

Competition should be viewed as a process. Open competitive markets provide opportunity. The standard approach undervalues the value of freedom to participate in markets. It typically pays short shrift to the broader societal cost, by which the allegedly efficiency inducing practices can tie up distribution and routes to market, creating entry barriers and reducing opportunity.

All of this implies that competition authorities should focus not just on mergers that reduce competition, or explicit agreements that lead to cartel or cartel like behavior or other plain vanilla antitrust violations, but rather on any conduct that is likely to prevent, lessen, or distort competition, for instance by (a) facilitating raising prices (e.g. by changing elasticities of demand for those setting prices-e.g. vertical restraints (Rey and Stiglitz 1988, 1995); (b) creating entry barriers; or (c) raising rivals' costs ${ }^{10}$. Such conduct should be proscribed, even if there might be some "public good" justification. Use should be made of a public interest test, not just in mergers but in conduct. More generally, competition policy should be concerned not just with the existence of competition, but with the nature of competition. It should work to ensure a competitive market place with reasonable ease of entry. In reality, the market itself creates some barriers to entry, e.g. in access to credit or technology. Competition authorities should be concerned about any practice that augments these natural barriers, thus increasing the market power that would, in any case, exist. And there should be a simple test of whether there is market power-the ability to raise prices or lower wages or impose anti-competitive constraints.

\section{NEW ISSUES WITHIN MORE STANDARD FRAMEWORK ${ }^{11}$}

Among the important abuses of market power today are several that are markedly different from those of the past. In particular, there are several instances of monopsony power (e.g. Amazon, Walmart), where a common test for acceptable behavior, whether consumers are advantaged, may fail to provide an accurate assessment of the consequences of the policy for societal well-being. In the short run, these monopsonists

\footnotetext{
${ }^{8}$ See Rey-Stiglitz $(1988,1995)$.

${ }^{9}$ Indeed, Stiglitz (1977) showed that in the presence of imperfect information, the major market distortions associated with monopoly were those connected with enhancing its ability to extract rents out of its customers.

${ }^{10}$ Krattenmaker and Salop (1986); Salop and Scheffman (1983).

${ }^{11}$ See Council of Economic Advisers (2016) for an insightful discussion of the increases in market power in the US, the potential adverse effects, including on inequality, and the new issues confronting antitrust and antitrust enforcement in the US.
} 
may advantage consumers, driving down the prices they pay and passing on a fraction of those gains. Of course, these gains are at the expense of producers. The gains to consumers are less than the losses of producers. This is a general implication of the fact that market power is distorting, lowering societal welfare.

In the long run, matters may be even worse. Thus, as Amazon drove down what authors received, there was, in effect, a transfer of resources from the creators of intellectual property to the merchants. While intellectual property is designed to encourage such creative activity, the impact of Amazon has been just the opposite.

Network externalities also present a new set of issues. (In such networks, the benefits that one member of the network has from being in the network depend on who else is in the network. A phone network is valuable if and only if there are people on the network that I want to talk to.) Network externalities may arise in an increasingly large number of sectors, such as personal computer operating systems, airline reservation systems, and financial networks. When they exist, they generate new sources of market power, market power that is sustained and enhanced by contract restrictions, such as those that restrict the ability of those participating in the network to pass on charges imposed on them to end users of the network. For instance, credit card companies charged merchants large fees (called interchange fees, typically 1-3\% of the value of the transactions), but did not allow merchants to pass on those charges to those who used the credit card-or even to tell their customers how much they were paying in interchange fees. Thus, credit card users had not incentive to use a more efficient payments mechanism. The abuse of this market power has generated for banks and airline reservation systems billions of dollars in profits, led to inefficiency in choices (e.g. of payments mechanisms), and stifled innovation.

Of particular concern is the attempt by members of the Chicago school and others to defend the abuses of this market power by their usual argument that markets are naturally competitive and efficient, in this case using the theory of two-sided markets. In that theory, the network operator may lower the price of some participants in the network to induce more to participate, enhancing the value of the network to others. Credit and debit card companies use this argument to justify, for instance, the exorbitant charges imposed on merchants, even when there is no analysis of (a) whether there really exist network externalities on both sides of the market; and (b) whether these network externalities could possibly justify or explain the charges imposed. The contract restrictions are defended as efficiency-enhancing-though I have never seen a persuasive argument that that is so. ${ }^{12}$

\footnotetext{
${ }^{12}$ In the interests of full disclosure: I have served as an expert witness in several cases (both credit card and airline reservation systems) where these issues have been litigated. For a court ruling that came down strongly with views consistent with those expressed here, see the case against American Express where the US district court ruled that the company violated antitrust laws (https://www.justice.gov/opa/pr/us-district-
} 
The increasing importance of network externalities, at least in certain industries, implies, to the contrary, that we should be increasingly concerned about abuses of market power: firms will take advantage of the often inherent market power that results, attempting to amplify and extend its magnitude, durability and scope.

There are other reasons that competition authorities should be increasingly on guard: as we move to a knowledge economy, fixed, sunk costs become relatively more important, and even small such costs can serve as a large barrier to entry, enabling an incumbent to sustain large profits without the threat of entry (in the knowledge that should there be entry, competition will drive down prices to the point where the entrant will lose money). ${ }^{13}$ While it may be impossible to eradicate this natural barrier to entry, competition authorities should do what they can to make sure that incumbents don't amplify and extend their market power.

Similarly, there is a worry that as we move to a service sector economy, many services are local in nature, with reputation for quality an especially important factor in choices. Imperfect information concerning quality can result in important barriers to competition. (More generally, we often underestimate the importance of the nontraded component in the goods we buy. Even if they are tradeable goods have to be delivered to the consumer and serviced; the fraction of the life-time value added arising from these services as a fraction of the total expenditure on the product may be large.) It will be important to understand the ways in which firms in this sector maintain and enhance their market power, and to develop effective remedies.

\section{New technique for exercising market power even when naturally acquired}

Antitrust has focused on preventing the creation of market power through mergers and anticompetitive practices, and the abuse of market power, however created. But, as the contractual arrangements used by the airline reservation systems and the credit and debit card systems illustrate, there has been innovation in creating, maintaining, and enhancing market power, and antitrust authorities will have to be increasingly aware of and innovative in responding to these "innovations." Microsoft's use of FUD (Fear, Uncertainty and Doubt), threats of lack of interoperability, and bundling of its browser with its operating system-effectively pricing the browser at zero-illustrate advances in anticompetitive practices. The market power created through the use of these

court-rules-american-express-violated-antitrust-laws). The case is currently under appeal. There has also been a settlement in cases against Visa and Mastercard. In the US, the Durbin Amendment to Dodd-Frank curtailed the abuses of debit card companies. European and Australian regulatory authorities have also taken actions attempting to limit the restrictive practices. Distributors have also often used similar contract restrictions to enhance their natural market power.

${ }^{13}$ See Stiglitz (1987), Dasgupta and Stiglitz (1988), and Stiglitz and Greenwald (2014). 
anticompetitive practices has persisted ${ }^{14}$, presenting antitrust authorities with still another challenge-how best to reverse market power once created, especially when it has been created through anticompetitive practices.

These issues are likely to become even more important as we move to a knowledgebased economy, with intellectual property rights (IPR) playing an increasingly important role. IPR gives firms monopoly power over their knowledge, and changes in IPR have provided corporations with increasing market power. Still, as the example of Microsoft illustrates, even when firms legitimately acquire market power through IPR, they do not have free license to abuse that market power through the use of anticompetitive practices.

Antitrust authorities should be sensitive to attempts by those in the corporate sector to amplify their market power through changes in our system of IPR. IPR is supposed to balance the dynamic benefits of innovation with the static costs of monopoly and restrictions in the use of knowledge (Stiglitz 2008). In fact, many in the corporate sector are arguing for strengthening intellectual property rights in ways which cannot be defended in any appropriate balancing the benefits of innovative incentives vs. the costs of monopoly. An obvious example is the extension of the life of copyright. There is no evidence of any innovative benefit of recent extensions (to 70 years beyond the death of the author).

Historically, anti-trust authorities have been sensitive to the power of patents to create, amplify, and increase the duration of market power. They forced AT\&T to put its patents into a pool, accessible by others. One of the proposals put forward to curb Microsofts' monopoly power was to limit the life of its patents. It was argued that these actions not only increase competition, but also innovation. (Furman and Stiglitz, 2002.)

The most egregious abuses perhaps occur in the drug industry, where, especially in trade agreements, Big Pharma has attempted to get provisions that allow it to "evergreen" its patents and to advantage itself at the expense of generics-often obtaining benefits that it could not have obtained in open public debate. (Data exclusivity is an example of one of the mechanisms by which they have attempted to extend the effective life of their patents.) Some of the practices-such as paying off generic firms not to enter-have already been attacked by antitrust authorities; but again, the industry has shown enormous ingenuity in creating market power, often in subtle ways, again often with the assistance of trade ministries. The US, for instance, has pushed for restrictions on the use of formularies, one way of encouraging

\footnotetext{
${ }^{14}$ The court's rulings on Microsoft's rampant anti-competitive practices has been remarkably narrow. The Department of Justice did not win its FUD, bundling, or zero price/predatory pricing counts. The DOJ did not appeal the zero pricing loss in the district court. It lost in the appellate court on the claim that bundling was per se illegal, and the DOJ opted not to retry that part of the case under a rule of reason.
} 
competition among drugs with similar benefits. Even worse was the provision in the US establishing a drug benefit for the elderly (called Medicare Part D), which restricted the ability of the US government to bargain with the drug companies over price. The voice of antitrust authorities needs to be heard more loudly in response to proposed provisions in trade agreements and public legislation.

\section{New approaches to antitrust}

Over the years, antitrust authorities have developed a set of approaches to establishing antitrust violations. Having such regular procedures provides clarity to firms and seemingly reduces the burden on the judiciary. Plaintiffs alleging an antitrust violation, for instance, have to define a market, in which the firm engaged in the alleged market abuse has a critical share. The presumption is that in the absence of a large market share (in some relevant market) it would be impossible for any firm to engage in anticompetitive abuses.

But increasingly, it is being recognized that this standard approach may be inadequate for dealing with some of the important anticompetitive abuses today, for instance when the relevant market is affected by market-imposed constraints. In the absence of these constraints, for instance, American Express, it might be argued, would not have market power in the credit card market; but with the anticompetitive constraints (e.g. that its merchants cannot use the price system, passing on some or all of the costs of different payment systems to its customers), it has enormous market power. That is, it has the ability to raise its price above the competitive level by a significant amount, with a small loss of usage. Indeed, even a firm with a very small market share (like Discover) has market power. ${ }^{15}$

I would argue that the lesson of these recent examples is that the key issue is actually simpler than that entailed in the standard approach: it is simply whether the firm, with its contract restrictions, has the power to raise prices-and whether it has the power to effectively force firms to agree to anticompetitive contract provisions. The question then is how did it get that market power and is it sustainable. In some cases, that market power resulted from a simple contract restriction which amplified some natural market power; the prohibition of that contract might, in such circumstances, significantly enhance competition in the market place.

\footnotetext{
${ }^{15}$ The underlying theory is called the theory of insistence.
} 


\section{BROADENING THE ANTITRUST AGENDA}

We began this paper by explaining how the antitrust agenda had been narrowed from a broader concern about power to a more narrow focus on certain "illegitimate" ways of creating market power and certain abuses of market power, once obtained. In this section, I want to argue that rather than narrowing the remit of competition policy, we should be broadening it, to reflect not only new risks associated with market power, but a broader realization of the limitations on the natural forces for competition and the broader uses to which competition policy may be put.

\section{New risks associated with market power}

There are in fact at least four new risks associated with market power, risks that were beyond anything conceivable to the progressives of the era in which antitrust legislation was first passed.

\section{(a) Using market power to induce individuals to give up rights of privacy.}

Some internet firms provide small discounts to individuals who agree to turn over their data to the firm. It is not clear that the individuals in doing so fully recognize the risks to themselves. Besides, there are societal consequences that go beyond the individual: putting broad databases together can result in those who control such data having power over individuals, and that power could be abused. There has long been a concern about government intrusion into privacy on precisely such grounds. But any private sector firm having such data could sell or be forced to turn over that data to the government. While there is no sure way of preventing abuses, not allowing firms to bribe their customers into turning over their data may be helpful. In any case, the collection of such data can give the internet firm a distinct advantage over rivals, and act as a barrier to entry. Thus, while what is at stake is more than the remit of standard competition authorities, there can be competition effects. $^{16}$

(b) Using market power to induce individuals to give up rights to use the public legal system for dispute resolution

This is another example where firms with market power use that market power to enhance their market power; and/or firms are taking advantage of ill-informed consumers to get an advantage over their consumers. Firms with market power can exploit their customers, e.g. with switch and bait techniques or not performing as

\footnotetext{
${ }^{16}$ Of particular concern is that these internet providers may already have market power; and they are using that market power to get agreements to transfer information to them will enhance their market power. And this is especially of concern in societies where there is great inequality and large fractions of the population may not be well educated.
} 
promised; but when the customer seeks redress, he is forced to use private arbitration.

Dispute adjudication is a basic public function. There are certain basic rights that individuals should not be able to give up, even for a price. The previous section illustrated one set, rights to privacy. It has long been recognized that an individual should not be allowed either to sell his vote or himself. So too, I believe, for the use of fair courts. By now, there is ample evidence on the lack of fairness of private arbitration.

\section{(c) Too-big-to-fail banks}

These represent a quite different kind of risk of "bigness" than those on which the trust-busters were focused. Too-big-to-fail banks have an incentive to engage in excessive risk taking because they know the government will rescue them. In fact, their plight gives them political power-and it was the abuse of political power with which the progressives were concerned. But the too-big-to-fail banks have proved their political power in another way: it has been virtually impossible to curb their power. As I pointed out (Stiglitz 2010), there was a rough political balance in the US, between 350 million Americans and ten banks, such that some legislation curbing the worst excesses was passed, but clearly, far less than the vast majority of Americans thought was desirable or necessary.

\section{(d) Inadequate competition in the market place of ideas}

The last illustrates well the limitations of current approaches, where the effect of media concentration is simply measured by market power in often narrowly defined advertising markets. Mergers across media (between television stations and newspapers) leading to markedly reduced access to different views have been allowed to go forth, simply because there is competition in the "relevant" market for advertising.

\section{Competition policy can and should be broadened further}

Until recently, the competitive equilibrium model was the benchmark model used by economists. It was argued, especially by economists from the Chicago School, that competition was the natural state towards which the economy tended, and deviations from this benchmark were limited. It was these limited deviations that were the subject of competition policy. Since the economy tended towards the competitive ideal on its own, only unnatural actions-like cartels-should be of concern. But today, there is a growing consensus that the real world entails extensive departures from this competitive benchmark model entails, with limitations of competition playing a key role in labor, capital, and most product markets. Indeed, there is a growing view that one cannot understand the functioning of most economies today without 
understanding these pervasive limitations in competition; a new benchmark model is emerging, one in which departures from competition are the norm rather than the exception. In this world, antitrust authorities seek not to restore the economy to some perfect competition ideal, but simply seek to prevent excessive and abusive concentrations of market power and the use of anti-competitive practices, particularly when they extend, augment, and deepen market power.

Within most countries, monopoly and monopsony power play an important role in explaining inequality; the growth in monopoly and monopsony power can thus play an important role in explaining the growth in inequality; and policies aimed at reducing market power can accordingly play some role in the reduction of inequality (Stiglitz 2015, Stiglitz et al 2015). The extent to which inequality reduction should be an explicit objective of competition policy remains a subject of debate ${ }^{17}$. But in its very nature of checking abuses of power, competition policy is about reducing inequalities in some fundamental sense. (See also Fox, 2016.)

\section{v. GLOBALIZATION}

The nature and intensity of competition depends on who is in the game. Many have argued with the growth of globalization, there are more firms competing in any marketplace, and therefore, there is a stronger presumption in favor of competition (that is, that markets are in fact competitive, so long as trade barriers are kept low). Earlier, we explained that, in fact, even in the case of traded goods, there is often a large non-tradable component, associated with the delivery and servicing. Hence, local market power can still matter.

Developing countries face an inherent and historic asymmetry of power. There is a broad philosophical issue: What does "fair" competition mean, in the context of a developing and emerging market, where small local firms have to compete with foreign behemoths? Is it fair to limit oneself to ensuring that the behemoth does not engage in certain exclusionary practices? Is that true even if some of its competitive advantage arises out of monopsony power in some third market (as described earlier)?

New approaches to development focus on "helping infant economies grow" (Greenwald and Stiglitz 2006; Stiglitz and Greenwald 2014), recognizing the externalities generated by new firms and industries, e.g. in the manufacturing sector, which in turn imply that a "free" market solution will not lead to (adequate) development. This provides a legitimate argument for protection-tilting the balance towards domestic firms by, for instance, maintaining a stable, real competitive exchange rate. But it is also an argument for more aggressive enforcement for antitrust. Antitrust policy, like any

${ }^{17}$ See Baker and Salop (2015). 
other policy arena, entails a balancing act, the risks of under and over enforcement. How that balance should play out depends on the circumstances of each individual country.

Thus, just like there should not be a single intellectual property regime for all countries $^{18}$, there should not be a single competition policy for all countries. Just as there should be a development oriented trade regime and a development oriented intellectual property regime, there should be a developmentally oriented competition regime and antitrust policy.

This is especially so because colonialism and imperialism were based on an asymmetry of political power; and the colonial/imperial countries used that power to entrench themselves economically and to disempower and exploit the countries that they subjugated. In economics, there are often large hysteresis effects: power, once established, extends and amplifies itself.

The ex-colonial powers were not content to simply rely on market forces to extend and amplify their market power; they embedded within the rules governing the postcolonial era measures that helped perpetuate these imbalances. Thus, escalating tariffs within the WTO rules-based system had the effect of leaving the developing countries to continue exporting low value-added raw materials, and ensuring that the higher value added activities occurred in the more developed countries. (See Charlton and Stiglitz, 2005)

Competition policy has an important role to play in undoing these historical legacies, enhancing the ability of developing and emerging countries to compete and promoting development more broadly.

In international trade agreements-ironically, sometimes under the guise of provisions labeled "competition"- developed countries, including both the US and those in the EU have attempted to restrict the ability of developing countries to compete. They have, for instance, argued that domestic content regulations are anticompetitive. In other fora, at the IMF and the World Bank, the advanced countries have discouraged developing countries from using industrial policies (including active exchange rate management) to become more competitive, in spite of the theory and evidence that such policies, when well managed, can be very effective. ${ }^{19}$ Without industrial policy supporting the development of capabilities and learning by doing and helping firms overcome barriers to entry (such as finance), countries will have low levels of domestic

\footnotetext{
${ }^{18}$ Stiglitz (2006) and references cited there and Cimoli et al (2014).

${ }^{19}$ See e.g. Greenwald and Stiglitz (2006) and Stiglitz and Greenwald (2014). More recently, the World Bank has changed its position, and has been actively promoting industrial policies. See Stiglitz and Lin (2014) and Lin (2014).
} 
rivalry. Under such circumstances, trade opening can increase the disadvantages of domestic firms and thus decrease effective competition.

The fact that the elimination of formal trade barriers does not create a level playing field has finally been recognized in the aid-for-trade movement. Without aid for trade, removing tariffs and other "artificial" trade barriers actually disadvantages developing countries. But the earlier literature on aid-for-trade didn't recognize its full implications for the extent of competition within the country. ${ }^{20}$

At the same time, domestic policies need to be wary of supporting national champions: dominant firms in many developing countries try to use the "national champion" argument to give them freedom to suppress competition at home and use and abuse their market power.

\section{MARKET POWER, INEQUALITY AND DEVELOPMENT}

While market power has long been front and center in competition policy, recent advances have, as we have noted, provided new arguments for the importance of attacking it. It leads to inequality, and inequality leads to poorer economic performance, including lower growth and more instability.

Market power is often associated with creating barriers to entry, and inequality means fewer people have resources to enter markets.

These problems can be particularly serious when foreign firms have market power. For then the resulting profits mean that resources get redistributed out of countrydepriving the country of needed foreign exchange and undermining demand for domestic non-traded goods, making it more difficult for the country to achieve a competitive market in these goods (including more difficult to achieve economies of scale).

\section{BROADENING THE MENU OF POSSIBLE ANTITRUST POLICIES ${ }^{21}$}

Earlier sections of this paper have emphasized the importance of broadening the scope of competition policy from the narrow remit to which the Chicago school attempted to condemn it. This section argues that there is, in fact, a broad menu of antitrust policies that competition authorities should employ. ${ }^{22}$

\footnotetext{
${ }^{20}$ See Charlton and Stiglitz (2006, 2008, 2013).

${ }^{21}$ This section has benefitted particularly from Baker and Salop (2015).

${ }^{22}$ A refrain of much of my policy work in development over the past twenty years has been that there was a need for "broader goals, more instruments," than had been suggested by the Washington Consensus, itself
} 
Earlier, we referred to the "public interest test." Within that, there can and should be explicit reference to some of the concerns raised in this paper: inequality, development, the marketplace for ideas. We referred too to the necessity of changing presumptions.

Of course, those who are engaged in anticompetitive practices, or who believe that markets are naturally competitive, have worked to weaken antitrust enforcement. There is a need to increase and focus agency enforcement, with increased antitrust agency budgets. There should be prosecutorial discretion to prioritize cases that benefit less advantaged consumers and to design remedies to benefit less advantaged consumers. ${ }^{23}$

Moreover, under the influence of "Chicago economics" there has been a hesitancy to take strong actions, seen most clearly in the Microsoft case, where the initial actions failed even to curtail the company from engaging in anticompetitive practices, and subsequent actions did little to curtail the market power that had already been established. There is a need for a rebalance, toward more interventionist antitrust and regulatory actions and standards. For instance, one of the proposed actions in the Microsoft case was to limit the term of its intellectual property. While such an action would have both stimulated innovation and curbed market power, this and similarly strong actions were rejected. ${ }^{24}$

Another example of how antitrust authorities could take stronger actions to promote competition is recognizing excessive pricing by dominant firms as an antitrust offense. EU competition law recognizes excessive pricing by a dominant firm as an abuse of dominance (as exploitative conduct). However, there have been very few cases. ${ }^{25}$ The US Sherman Act is narrower. A monopolist with legitimately obtained and maintained monopoly power is permitted to charge high prices. A "conduct element" is required, such as an agreement or an act of exclusion. (Interestingly, the US sets prices through antitrust in at least one area-rates for music publishing rights.) The US and other competition authorities could and should adopt the EU approach. ${ }^{26}$

Any jurisdiction will, of course, worry about the dangers and costs of under- vs. overenforcement. But in setting the rules account should be taken of economies' different

largely based on neo-liberal/Chicago school economic perspectives. See Stiglitz (1998, 2013a, 2013b, 2016) and various chapters in Kennedy and Stiglitz (2013) for a discussion of the relationship between Chicago school economics and the evolution of doctrines related to law and economics.

${ }^{23}$ Thus, under current US law, the Federal Trade Commission (FTC) could conclude that monopoly pricing or price discrimination targeting less advantaged consumers violates the FTC Act.

${ }^{24}$ See Furman and Stiglitz (2002).

${ }^{25}$ Somewhat disturbing, my understanding is that a recent decision by the Competition Appeal Court in South Africa may make a finding of excessive pricing difficult.

${ }^{26}$ To implement this standard in the US, legislation would be needed. 
characteristics and histories. Because of sunk costs, history matters. But when that history is colored by colonialism and oppression, that history cannot be ignored: there is an obligation on competition authorities to take a more pro-active stance in rectifying these imbalances.

Among the differences in circumstances facing different economies is size: Smaller economies may face greater problems of entrenched dominant firms. By the same token, natural entry barriers at earlier stages of development imply greater costs associated with exclusionary behavior, with effects that may be more persistent, outweighing risks of a "chilling effect" of stronger antitrust enforcement.

I would argue that there is a broad role of government to actively encourage competition, recognizing that competition does not simply and naturally arise in the absence of cartels, contrary to the Chicago school presumptions noted earlier. The industrial policies referred to earlier are one important instrument for encouraging entry and competition. A public option is another relevant one, at least for some sectors, where the government provides an alternative to the private sector, thereby checking the extent to which it can engage in exploitation. Thus, the public option in health insurance in the US might have played an important role in breaking anticompetitive behaviors that were hard to prosecute under existing laws; a public option in annuities might have led to more competitive insurance markets; and the public option in student loans has led to access at a more competitive rate. A public option in the market for conventional mortgages would almost surely bring down the cost of borrowing.

Competition authorities should recognize too that strong competition policy encourages entry. Microsoft's predatory actions have almost surely had a chilling effect on entry in that sector; had there been more confidence that antitrust authorities would have taken actions against those actions, there might have been more entry.

\section{Competition and public interest}

Earlier, I argued that public interest should be the over-riding concern of competition policy. But this broad mandate may be difficult to incorporate easily within a rulesbased competition framework, and the burden imposed on competition policy must take into account the existence of other instruments.

One principle, though, seems clear: Mandates on domestic firms (like lending to underserved communities or participation of historically disadvantage persons) should be imposed on foreign firms, even if it is more difficult for them to fulfill such a mandate. No country should sign trade or investment agreement that makes this difficult or impossible. 


\section{GLOBAL PERSPECTIVES}

Competition (when firms are active across borders) is a global public good. As in so many areas within global economics, there is a need for more global cooperation. Globalization implies that what happens in one jurisdiction has effects on those living in others. There is a need for collective action-which is not the same thing as saying that there is the need for the same rules, and especially if those rules are written by the advanced countries.

There should be cooperation in international enforcement-in the arena of mergers and cartels as well as conduct. ${ }^{27}$ The hypocrisy of almost studiously ignoring export cartels (like oil and potash)-which the international community has done-needs to be addressed.

What is clear, though, is that there is a need for a broader regulatory environment for multinationals, including taxation ${ }^{28}$. Competition policy should be seen as part of establishing this broader global cooperative framework.

Unfortunately, competition policy is increasingly seen as a weapon of national economic policy. Moreover, there are economic as well as political reasons for being easier on domestic firms that engage in anticompetitive practices-some of the profits they glean are at the expense of citizens and firms in foreign countries; their exclusionary practices may benefit domestic employment at the expense of foreign employment; and some of the increased profits will redound to the benefit of the government.

Thus, it is perhaps not a surprise that the US is now accusing Europe of unfairly using competition policy against American firms. The US government is more susceptible to pressure from US firms, and it may well be that the US government sees not only political but economic benefits arising from the success of American firms, even if that success is partially based on anti-competitive practices (or practices of avoiding taxes within Europe). And Europe worries that companies like Google and Facebook will not only open up the possibility of the misuse of the information that they are gathering, e.g. by some governmental body, but that these firms will also use their privileged access to information to entrench themselves.

\footnotetext{
${ }^{27}$ This does not, however, mean that there should be the same policies in all countries, as we noted earlier.

${ }^{28}$ The failure of the UN conference on Finance for Development (in Addis Abba, July, 2015) to establish even the beginnings of such a framework within the UN highlights the difficulties. The advanced countries are used to making the rules by themselves, for the benefit of themselves.
} 


\section{BRICS cooperation}

Cooperation among BRICS can be an important step in creating that global framework: working together to understand better and create a developmentally oriented competition regime, one of the objectives of which is promoting inclusive growth.

This developmentally oriented competition regime must be based on the recognition that many of the central economic doctrines that have dominated Western competition policy have been discredited, or at least have more limited reach than previously realized.

Cooperation among the BRICS competition authorities can be helpful in sharing insights, and perhaps with more explicit cooperation, in ensuring more competition in areas where in the past competition has been limited.

Implementing this broader agenda that I have laid out here will not be easy. But not implementing this broader agenda risks losing important opportunities for promoting inclusive development. 


\section{REFERENCES}

Akerlof, G.A. and R.J. Shiller, 2015, "Phishing for Phools: The Economics of Manipulation and Deception,” Princeton, New Jers.: Princeton University Press.

Arrow, K.J. and G. Debreu, 1954, "Existence of an equilibrium for a competitive economy," Econometrica 22(3): 265-290.

Baker, J.B. and S.C. Salop, 2015, “Antitrust, competition policy and inequality,” mimeo, Georgetown University Law Center.

Chamberlain, E., 1933, The Theory of Monopolistic Competition, Cambridge, Mass.: Harvard University Press.

Charlton, A. and J.E. Stiglitz, 2005, Fair Trade for All, New York: Oxford University Press, 2005

2006, “Aid for trade,” International Journal of Development Issues, 5(2): 1-41. (Reprint of paper prepared for Commonwealth Secretariat).

-- 2008 "Aid for trade," Keynote Address, Annual World Bank Conference on Development Economics 2007, Rethinking Infrastructure for Development, F. Bourguignon and B. Pleskovic, eds., World Bank: Washington, DC, pp. 29-46.

- - 2013, "The Right to Trade: Rethinking the Aid for Trade Agenda," in Assessing Aid for Trade: Effectiveness, Current Issues and Future Directions, Mohammad A. Razzaque and Dirk Willem te Velde (eds.), London: Commonwealth Secretariat, pp. 359-386.

Cimoli, M., G. Dosi, K.E. Maskus, R.L. Okediji, J.H. Reichman, and J.E. Stiglitz, 2014, Intellectual Property Rights: Legal and Economic Challenges for Development, Oxford and New York: Oxford University Press.

Council of Economic Advisers, 2016, "Benefits of Competition and indicators of market power",

April. Available at

https://www.whitehouse.gov/sites/default/files/page/files/20160414_cea_competition_issu e_brief.pdf

Dasgupta, P. and J. E. Stiglitz, 1988, "Potential Competition, Actual Competition and Economic Welfare,” European Economic Review, 32, May, pp. 569-577.

Diamond, P.A., 1971, “A model of price adjustment," Journal of Economic Theory, 3(2): 156-168. 
Dixit, A. and J. E. Stiglitz, 1977, Monopolistic Competition and Optimum Product Diversity, American Economic Review, 67(3): 297-308.

Fox, Eleanor, 2016, “Making Markets Work for the People,” paper presented to BRICS competition conference, Durban, November 2015 to be published in proceedings.

Fox, Eleanor, 2014, Monopolization and Abuse of Dominance: Why Europe is Different, Antitrust Bulletin, 59 (1): 129-152

Fox, Eleanor, 2008, The Efficiency Paradox, in How Chicago School Overshot the Mark: The Effect of Conservative Economic Analysis on U.S. Antitrust, R. Pitofsky, ed., 77-101.]

Furman, J. and P. Orszag, 2015, "A Firm-Level Perspective on the Role of Rents in the Rise in Inequality.” October, Presentation at “A Just Society”, Centennial Event in Honor of Joseph Stiglitz, forthcoming in Festschrift, New York: Columbia University Press.

Furman, J. and J. E. Stiglitz, 2002, "U.S. versus Microsoft, Declaration as Part of The Tunney Act Proceeding,” commissioned by the Computer \& Communications Industry Association, Jan. 28. Available at http://www.sbgo.com/Papers/tunney_jesjf.pdf

Greenwald, B. and J.E. Stiglitz, 1986, "Externalities in Economics with Imperfect Information and Incomplete Markets,” Quarterly Journal of Economics, 101 (2): 229-264.

-- 2006, "Helping Infant Economies Grow: Foundations of Trade Policies for Developing Countries," American Economic Review: AEA Papers and Proceedings, 96(2): 141-146. Kennedy, D. and J.E. Stiglitz, 2013, Law and Economic Development with Chinese Characteristics: Institutions for Promoting Development in the Twenty-First Century, Oxford and New York: Oxford University Press.

Krattenmaker, T.G. and S.C. Salop, 1986, "Competition and Cooperation in the Market for Exclusionary Rights,” American Economic Review, 76(2): 109-13.

Lin, J.Y., 2014, "Industrial Policy revisited: A new Structural Economics Perspective," Revue d’économie du développement, De Boeck Université, vol. 22(HS01): 51-70.

OECD, 2014, "Focus on Inequality and Growth," December. Available at http://www.oecd.org/social/Focus-Inequality-and-Growth-2014.pdf. 
Ostry, J., A. Berg, C.G. Tsangarides, 2014, "Redistribution, Inequality, and Growth,” IMF Staff $\begin{array}{llll}\text { Discussion } & \text { Note, } & \text { February. } & \text { Available }\end{array}$ http://www.imf.org/external/pubs/ft/sdn/2014/sdn1402.pdf.

Rey, P. and J.E. Stiglitz, 1988, "Vertical Restraints and Producers' Competition,” European Economic Review, 32, pp. 561-568.

--_-, 1995, “The Role of Exclusive Territories in Producers' Competition,” with P. Rey, Rand Journal of Economics, 26(3): 431-51.

Rothschild, M. and J. E. Stiglitz, 1976, "Equilibrium in Competitive Insurance Markets: An Essay on the Economics of Imperfect Information,” Quarterly Journal of Economics, 90(4): 629-649.

Rey, Patrick and J. E. Stiglitz, 1988 "Vertical Restraints and Producers' Competition," European Economic Review, 32(2-3): 561-568.

- - 1995, "The Role of Exclusive Territories in Producers' Competition," Rand Journal of Economics, 26(3): 431-51.

Salop, S.C. and D.T. Scheffman, 1983, "Raising Rivals' Costs,” American Economic Review, 73(2): 267-71.

Smith, A., 1776, An Inquiry into the Nature and Causes of the Wealth of Nations, London: W. Strahan and T.Cadell.

Stiglitz, J.E., 1977, “Monopoly, Non-Linear Pricing and Imperfect Information: The Insurance Market," Review of Economic Studies, 44(3): 407-430. Reprinted in Selected Works of Joseph E. Stiglitz, Volume I: Information and Economic Analysis, Oxford: Oxford University Press, 2009, pp. 168- 192.

--1987, "Technological Change, Sunk Costs, and Competition," Brookings Papers on Economic Activity, 3: 883-947

-- 1998, "More Instruments and Broader Goals: Moving Toward the Post-Washington Consensus," in Development Issues in the $21^{\text {st }}$ Century, G. Kochendorfer-Lucius and B. Pleskovic (eds.), Berlin: German Foundation for International Development, 1999, pp.1139. Also Chapter 1 in The Rebel Within, Ha-Joon Chang (ed.), London: Wimbledon Publishing Company, 2001, pp.17-56. (Originally presented as the 1998 WIDER Annual Lecture, Helsinki, January 1998; also keynote address at Villa Borsig Winter Workshop, February 1998.) 
-- 2002, "Information and the Change in the Paradigm in Economics," abbreviated version of Nobel lecture, American Economic Review, 92(3): 460-501.

-- 2006, Making Globalization Work, New York: W.W. Norton.

-- 2008, "The Economic Foundations of Intellectual Property," sixth annual Frey Lecture in Intellectual Property, Duke University, February 16, 2007, Duke Law Journal, 57(6): 16931724 .

-- 2010, Freefall: America, Free Markets, and the Sinking of the Global Economy, New York: W.W. Norton.

-- 2012, The Price of Inequality: How Today's Divided Society Endangers our Future, New York: WW Norton.

-- 2013a, The Economics Behind Law in a Market Economy: Alternatives to the Neoliberal Orthodoxy, in Law and Economic Development with Chinese Characteristics: Institutions for the 21st Century, J.E. Stiglitz and D. Kennedy (eds.), Oxford and New York: Oxford University Press, pp. 153-186.

-- 2013b, "Creating the Institutional Foundations for a Market Economy," in Law and Economic Development with Chinese Characteristics: Institutions for the 21st Century, J.E. Stiglitz and D. Kennedy (eds.), Oxford and New York: Oxford University Press, pp. 71-111.

-- 2015, "New Theoretical Perspectives on the Distribution of Income and Wealth Among Individuals: Parts I-IV” NBER Working Papers 21189-21192, May 2015.

-- 2015, N. Abernathy, A. Hersh, S. Holmberg, and M. Konczal, Rewriting the rules of the American economy: an agenda for growth and shared prosperity, New York: W.W. Norton (The Roosevelt Institute, May http://www.rewritetherules.org.)

-- 2016, “The state, the market, and development”, WIDER working paper 1/2016, February. Originally presented at a conference celebrating WIDER's $30^{\text {th }}$ anniversary, September 18 , 2015.

-- and B. Greenwald, 2014, Creating a Learning Society: A New Approach to Growth, Development, and Social Progress, New York: Columbia University Press. Reader's (abridged) edition published 2015. Also published in Spanish by La Esfera de los Libros. 
-- and J.Y. Lin, 2014, "The Industrial Policy Revolution I: The Role of Government Beyond Ideology, Houndmills, UK and New York: Palgrave Macmillan 